\title{
Myopericytoma arising from myopericytosis-a hitherto unrecognized entity within the lung
}

\author{
Ulrike Gruber-Moesenbacher ${ }^{1} \cdot$ Alicia Morresi- Hauff ${ }^{1} \cdot$ Katja Behr $^{2} \cdot$ Helmut Popper $^{3}$ (i)
}

Received: 18 August 2020 / Revised: 28 October 2020 / Accepted: 15 November 2020 / Published online: 26 November 2020

(C) The Author(s) 2020

\begin{abstract}
Two cases of myopericytosis combined with pericytoma originating within the lung are reported. These are rare pulmonary tumors. The differential diagnosis for hemangiopericytoma and pericytic tumors with glomus elements is discussed. Both myopericytic lesions mimic other lesions, which are more commonly seen in the lung. Based on the expression of vascular growth factor receptors 2 and 3, an antiangiogenic therapy was suggested for the patient with the myopericytoma. A treatment with an angiogenesis inhibitor resulted in a regression of the tumor, but not the precursor lesion. Probably a more specific therapy using tyrosine kinase inhibitors for VEGFR2/3 might better control these myopericytic proliferations.
\end{abstract}

Keywords Myopericytosis $\cdot$ Myopericytoma $\cdot$ Pericytic tumor $\cdot$ Lung

\section{Introduction}

Pericytic tumors are rare tumors encountered in the lung. They comprise a spectrum of hemangiopericytoma, infantile myofibromatosis, tumors with glomus elements, and smooth muscle cells. They all show a perivascular proliferation intimately associated with blood vessels. They can form large tumors but also diffuse spreading lesions with multicentricity. The vascular structures can be prominent as in hemangiopericytoma, or branching vessels with epithelioid cells as in glomangiopericytoma. Some tumors lack these prominent vascular structures but show more smooth muscle cell proliferations as in myopericytoma [8]. Most tumors in this pericytic lineage have been described in soft tissues and skin, whereas they are rare in the lung $[1,20,33]$. Another tumor, solitary fibrous tumor, which is frequently encountered in the pleura may also occur within the lung and previously was confused with pericytic tumors. However, due to its characteristic molecular alteration (STAT6-NAB2 fusion), SFT can be clearly separated from the pericytic tumors [26].

Helmut Popper

helmut.popper@medunigraz.at

Institute of Pathology, Helios Clinics, Gauting, Germany

Institute of Pathology, Mittelthueringen, Bad Berka, Germany

3 Institute of Pathology, Medical University of Graz, Neue Stiftingtalstrasse 6,8036 Graz, Austria
Here, we report on two precursor lesions for myopericytoma arising primarily within the lung with quite different morphologies, in one case also with a subsequent tumor development. In addition, we identified a treatment option for this kind of tumors.

\section{Clinical history}

\section{Case 1}

A female patient aged 41 years presented with bilateral reticulonodular infiltrates. An open lung biopsy was taken. Due to some small cysts and the bilateral infiltration, a different diagnosis was made in an outside pathology department and by a consultant.

Five years later, the patient presented with the same reticulonodular infiltrations but in addition with a large nodular mass in the left hemithorax (Fig. 1). A fine needle biopsy was taken from the mass. This biopsy was received for consultation and also the original tissue was submitted for rereview.

After a diagnosis was established, the patient initially was treated with antihormonal therapy because of focal positivity of tumor cells for progesterone receptor. Surgery was excluded because of the preexisting diffuse process in both lungs. As this did not result in any improvement, chemotherapy was installed but withdrawn because of tumor progression. 


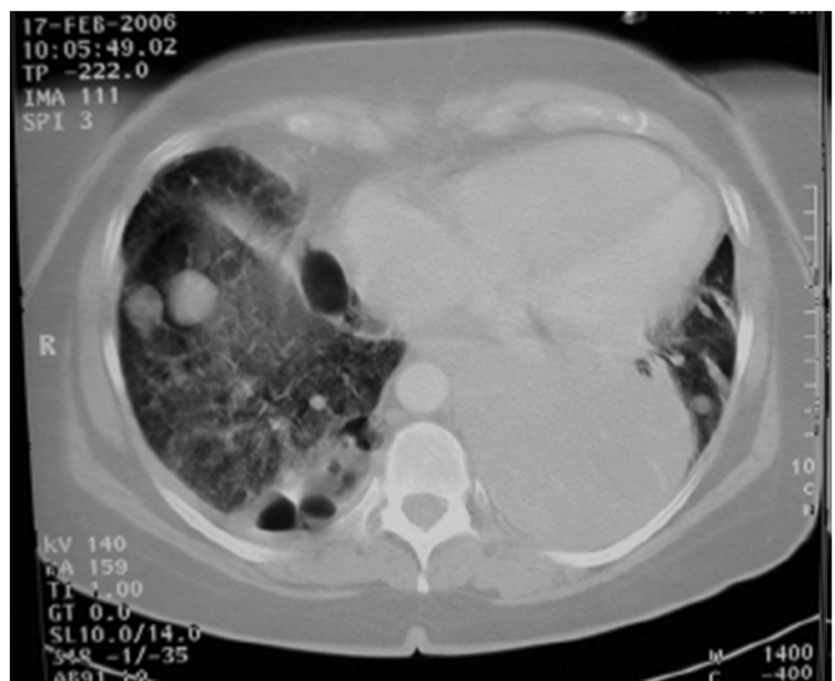

Fig. 1 CT scan showing the large tumor in the left lung of patient 1

Based on the results of the pathological examinations and suggestions for a change in the therapy protocol, gemcitabine combined with bevacizumab was administered. This resulted in a dramatic tumor shrinkage within 6 weeks, but the reticulonodular infiltrates did not change much. During the antiangiogenic therapy, massive bleeding occurred, which necessitated interruption of the treatment. After 2 months, a recurrence of the tumor was noted on control CT scan, and the patient was asked to continue the therapy. However, the patient refused further treatment and finally died 2 months later. No autopsy was performed.

\section{Case 2}

An 82-year-old female patient presented with a tumor nodule in the left lower lobe, and in addition with small trabecular infiltrations. In addition to a tumor, also lymphangioleiomyomatosis was suspected. An open lung biopsy was taken. An adenocarcinoma was diagnosed but additional nodular and trabecular infiltrations were recognized, which did not fit into any suspected diagnosis. Therefore, the tissues were sent for consultation.

\section{Material and methods}

Tissue blocks were received from both patients. Fourmicrometer-thin sections were stained by hematoxylin and eosin (H\&E), followed by a series of immunohistological investigations (Table 1). An informed consent was received from the patients; an ethical vote was issued by the Ethics Committee of the Medical University (EK 24-135 ex 11/12). All clinical data were anonymized.

\section{Results}

\section{Morphology of diffuse and nodular lesions of case 1}

Four years before the tumor was recognized, open lung biopsies had been taken, because of diffuse bilateral lung infiltrations; a Langerhans cell histiocytosis was suspected. In these biopsies, several nodular lesions with a diameter of up to $1.2 \mathrm{~mm}$ were seen in addition to diffuse dark-stained infiltrations (Fig. 2a). On higher magnification, a dense infiltration by cells with round-to-spindle-shaped dark nuclei and a basophilic, focally clear cytoplasm was seen in the nodular and diffuse lesions (Fig. 2b, c). A few larger cells with clear cytoplasm were seen (Fig. 2d). These cells showed an intimate association with blood vessels. The pneumocyte layers were unaffected.

The tumor was composed of similar cells (Fig. 2e), but there were more clear cells and even some giant cells (Fig. 2f). Focally, cells presenting with spindle cell morphology and cytoplasmic filaments were suggestive for smooth muscle cells (Fig. 2f).

\section{Morphology of trabecular lesions in case 2}

Besides the adenocarcinoma, only diffuse infiltrations were seen. On low magnification, these sheets of presumable epithelial or epithelioid cells resembled neuroendocrine cell or multinodular pneumocyte hyperplasia (Fig. 3a, b). On higher magnification, the cells presented with round slightly enlarged nuclei and an eosinophilic cytoplasm (Fig. 3c, d, e). Clear cells were rare. These proliferations, too, were intimately associated with blood vessels (Fig. 2e). Focally, the cells changed to a more spindle cell morphology and presented cytoplasmic filamentous structures (Fig. 2c, e).

Immunohistochemistry of both reticulonodular lesions including the tumor in case 1 (Table 2) was negative for two different pan-cytokeratin and cytokeratin 7 antibodies, neuroendocrine markers (CGA, Synaptophysin, PG9.5), S100 protein, vascular markers (CD31, CD34, factors VIIIAG and XIII, ERG) (Fig. 4a, b, c), podoplanin, common leukocyte antigen (CD45), calretinin, TTF1, p40, and desmin.

Both lesions and the tumor were in part positive for smooth muscle actin (SMA) (Fig. 4g, h), progesterone receptor, and vimentin (Fig. 4d). Either vascular endothelial growth factor receptor 2 or 3 (VEGFR2, VEGFR3) (Fig. 4e, f), vascular endothelial growth factor A (VEGF-A), or endothel kinase Tie2 was positive. Tuberin was positive in the diffuse process in case 1 ; single cells in case 2 were stained positively for caldesmon and MyoFD5. HMB45 was positive in few tumor cells of case 1, but negative in case 2. MITF and Melan A were negative in case 2 and hamartin in case 1 (for details, see Table 2). Cathepsin $\mathrm{K}$ was negative in case 2 , whereas platelet-derived growth factor B (PDGFRB) (Fig. 4i, j) was 
Table 1 List of antibodies, dilution, and visualization

\begin{tabular}{|c|c|c|c|}
\hline Antibody & Source & Dilution & Visualization \\
\hline Pancytokeratin & Dako clone HNF116, & $1: 100$ & Ventana ultraView \\
\hline CD 56 (NCAM) & Novocastra clone 1B6 & $1: 100$ & Ventana ultraView \\
\hline LCA CD45 & Dako clone PD7+2B11 & $1: 4000$ & \\
\hline S100 protein & Dako & $1: 2000$ & Protease XXIV Dako ENV (K5007) \\
\hline Vimentin & Linaris clone V9 & Ready to use & \\
\hline Desmin & Dako clone DE-R11 & $1: 200$ & \\
\hline Smooth muscle actin & Sigma clone 1A4 & $1: 5000$ & CC1 Ventana ultraView \\
\hline CD31 & Dako clone JC70A & $1: 50$ & Protease XXIV Dako ENV (K5007) \\
\hline CD34 & Neomarkers clone QBEnd10 & $1: 800$ & CC1 Ventana ultraView \\
\hline CD68 & Dako clone KP1 & $1: 300$ & Prot1 Ventana iview \\
\hline $\mathrm{Ki} 67$ & Ventana clone $\mathrm{K} 2$ & Ready to use & \\
\hline HMB45 & Dako clone HMB45 & $1: 100$ & \\
\hline ER & Dako clone 1D5 & Ready to use & \\
\hline PG & Dako clone PgR636 & Ready to use & \\
\hline VEGF-A & Santa Cruz clone $1-20$ & $1: 500$ & MW Tris Dako ENV (K5007) \\
\hline VEGFR-2 & Santa Cruz clone A3 & $1: 50$ & CC1 Ventana iview \\
\hline VEGFR-3 & Santa Cruz clone c-20 & $1: 200$ & CC1 Ventana iview \\
\hline Endothel kinase Tie2 & Santa Cruz clone H176 & $1: 50$ & CC1 Ventana iview \\
\hline cAMP kinase alpha & Santa Cruz & $1: 200$ & \\
\hline Hamartin & Santa Cruz clone $\mathrm{H} 300$ & $1: 50$ & CC1 Ventana iview \\
\hline Tuberin & Santa Cruz clone N19 & $1: 100$ & CC1 Ventana iview \\
\hline Calretinin (SP65) & Ventana $790-4467$ & Rtu & CC1 Ventana ultraView \\
\hline Podoplanin D2-40 & Dako M3619 & $1: 100$ & MW6,0 Dako ENV(K5007) \\
\hline Factor VIIIAG (F8/86) & Dako M0616 & $1: 1000$ & Prot1 Ventana iview \\
\hline HHV8 & Novocastra 13B10 & $1: 25$ & \\
\hline CD35 & Dako clone Ber MAC DRC & $1: 10$ & \\
\hline Cytokeratin 7 Clone OV-TL & Dako M7018 & $1: 100$ & Protease Dako ENV (K5007) \\
\hline CAM5.2 & BD Bioscience 345779 & Rtu & Prot1 Ventana ultraView \\
\hline $\mathrm{AE} 1 / 3$ & Dako M3515 & $1: 50$ & Protease Dako ENV (K5007) \\
\hline Chromogranin A Ab3 & Thermo Scientific MS-382-P & $1: 3000$ & $\mathrm{CC} 1$ Ventana ultraView \\
\hline Synaptophysin & Dako M7315 & $1: 50$ & CC1 Ventana ultraView \\
\hline Estrogen receptor EP1 & Dako IR084 & Rtu & Dako Omnis high pH \\
\hline Progesterone receptor PgR1294 & Dako GA090 & Rtu & Dako Omnis high $\mathrm{pH}$ \\
\hline TTF1 (8G7G3/1) & Dako 3575 & $1: 100$ & MW9,0 Dako ENV (K5007) \\
\hline P40 BC28 & Ventana $790-4950$ & Rtu & CC1 Ventana OptiView \\
\hline HMB45 & Dako GA052 & Rtu & Dako Omnis high $\mathrm{pH}$ \\
\hline MelanA A103 & Dako IR633 & Rtu & Dako Omnis high $\mathrm{pH}$ \\
\hline MITF Clone D5 & Dako M3621 & $1: 40$ & MW Tris Dako ENV (K5007) \\
\hline MIB1 Ki67 & Dako GA6266 & Rtu & Dako Omnis low pH \\
\hline Vimentin C9 & Dako GA630 & Rtu & Dako Omnis high pH \\
\hline Desmin D33 & Cell Marque 243M-16 & $1: 50$ & CC1 Ventana ultraView \\
\hline Factor XIII & Calbiochem 233498 & $1: 1000$ & Prot1 Ventana iview \\
\hline ERG EPR3864 & Abcam ab133264 & $1: 200$ & CC1 Ventana ultraView \\
\hline $\mathrm{S} 100$ protein & Dako GA504 & Rtu & Dako Omnis low pH \\
\hline Caldesmon h-CD & Dako GA054 & Rtu & Dako Omnis high $\mathrm{pH}$ \\
\hline MyoD1 5.8A & Dako M3512 & $1: 50$ & MWDako6,0 Dako ENV (K5007) \\
\hline Cathepsin K & Abcam ab37259 & $1: 1000$ & CC1 Ventana ultraView \\
\hline PDGFR beta & Neomarkers RB1692-P & $1: 100$ & MW pH 9.0, 150W, Dako Envision K5007 DAB \\
\hline
\end{tabular}

positive in the lesions from case 2 . Case 1 could not be evaluated because the tumor tissue was completely consumed.

\section{Discussion}

Both cases presented with a multifocal diffuse infiltration, in case 1 associated with small nodules. Four years later, a large tumor was seen on CT scan. An epithelial nature of the tumor cells was excluded by immunohistochemical stains for epithelial markers. For these lesions, several differential diagnoses were raised: A lymphoid lesion was excluded in case 1 , and a neuroendocrine proliferation in case 2 . Because of the intimate association with blood vessels in both cases, different endothelial markers were investigated, which highlighted the blood vessels within the proliferation, but were negative for the tumor cells. A pure smooth muscle cell proliferation was excluded, because many cells were negative for myogenic 
markers; however, cells within these lesions focally stained for SMA. Precursor lesions for a solitary fibrous tumor in case 1 could be excluded by negativity for CD34. Solitary fibrous tumor can occur within the lung and sometimes present with a hemangiopericytic pattern; however, additional to CD34, which was negative in both cases, they express STAT6, which was negative in case 2 also. Case 2 resembled a multifocal pneumocyte hyperplasia [23], but as it was negative for cytokeratin and TTF1 could be excluded. Diffuse neuroendocrine hyperplasia also can mimic the lesions in case 2 . However, a negative reaction for neuroendocrine markers and cytokeratin helped to exclude this entity too.

Hemangioma or glomangioma patterns were not present in both cases. The majority of the diffuse proliferation in both cases was positive for the mesenchymal marker vimentin, and there were few clear cells positive for HMB45 in case 1. A
PEComa could be excluded in case 2 due to negativity for MITF and cathepsin K $[5,18]$. This all pointed to a pericytic differentiation. Pericytes in the fetal period are responsible for the formation of the outer vascular wall, whereas the endothelia are formed from bone marrow-derived mesenchymal precursor cells [2]. Pericyte precursor cells differentiate into smooth muscle cells, pericytes, and perivascular epithelioid cells (PEC) $[3,24]$. This can be seen in both cases: focally, these cells differentiated into smooth muscle cells, and in the tumor, focal HMB45-positive perivascular epithelioid cells (PEC) are seen. In the diffuse proliferation in case 1, there were some associated endothelial proliferations with doubling of capillaries, but again no classical angiomatous pattern, such as endothelial-lined vascular spaces $[1,33]$, which excludes a hemangiopericytoma. Hemangiopericytomas have been described in the lung, expressing smooth muscle cell and
Fig. 2 Case 1: a Overview with two nodules and diffuse darkstained precursor lesion. H\&E, bar $1 \mathrm{~mm}$; $\mathbf{b}$ and $\mathbf{c}$ medium and high magnification of the proliferation in the nodules. Note the spindle cells with small clear cytoplasm and their intimate association with blood vessels. $\mathrm{H} \& \mathrm{E}$, bars $0.1 \mathrm{~mm}$ and $50 \mu \mathrm{m}$. d High magnification of the diffuse lesion. The lesion is composed of spindle cells with small clear cytoplasm closely associated with small blood vessels. H\&E, bar 20 $\mu \mathrm{m}$. e Overview of the

myopericytoma. The tumor cells are associated with thin-walled blood vessels and are spindle shaped. H\&E, bar $0.5 \mathrm{~mm}$. f High magnification of the tumor cells. There are more epithelioid clear cells, some of them positive for HMB45, some giant cells with large nuclei, and also cells with myofilaments. H\&E, × 400
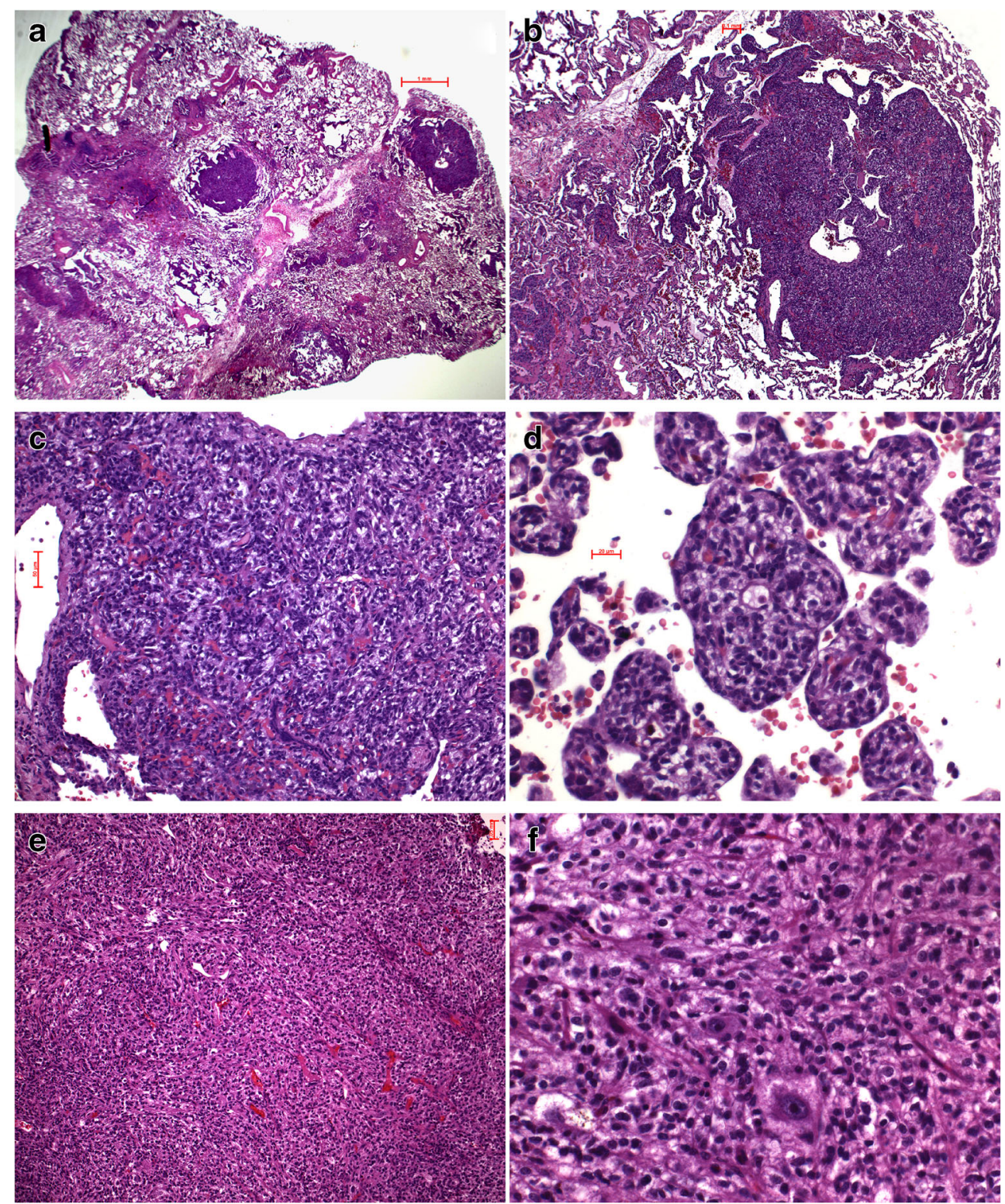
Fig. 3 Case 2: $\mathbf{a}$ and $\mathbf{b}$ show an overview of two of the multifocal lesions. H\&E, $\times 50$. In $\mathbf{c}, \mathbf{d}$, and $\mathbf{e}$, higher magnification from several of these lesions is shown. Note the epithelioid cells, resembling diffuse neuroendocrine hyperplasia or also multiple nodular pneumocyte hyperplasia. In $\mathbf{c}$ and $\mathbf{e}$, the differentiation into smooth muscle cells is suggested. $\mathrm{H} \& \mathrm{E}, \times 200$

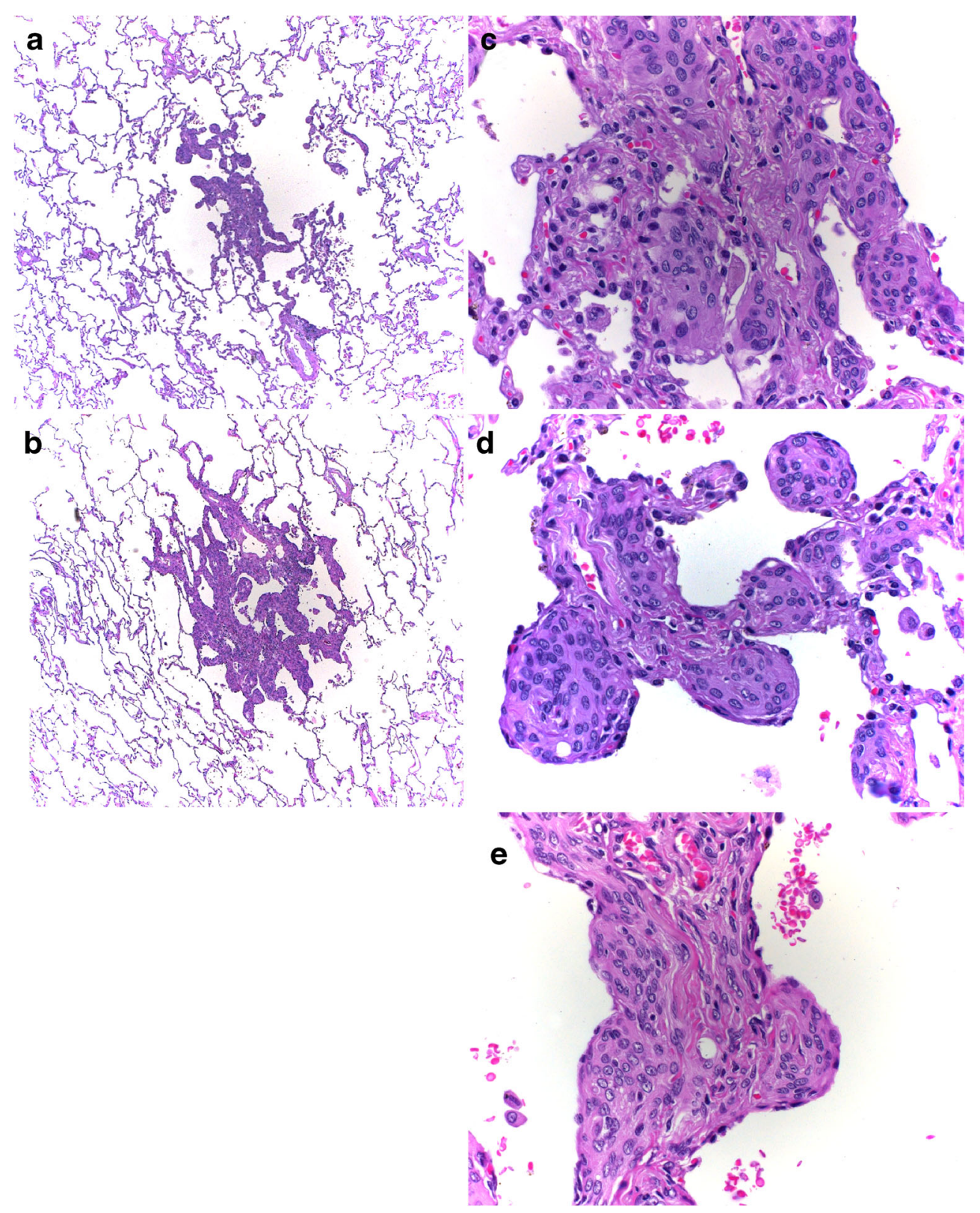

endothelial markers $[1,4,12,15,17,29,32,33]$. Glomus tumors and glomangiopericytoma have also been reported $[9,16,27,28]$. Our second case somehow resembled a glomus tumor or glomangiomyoma, but it lacked the angiomatoid structures; with respect to glomangiopericytoma, the prominent thin- and thick-walled blood vessels were missing. In addition, desmin staining was absent in both cases. As no extensive fibrous tissue was noted and also only a minority of tumor cells expressed SMA, an angiocentric myofibromatosis could be excluded [7]. But both cases very nicely show the evolution of this lesion from pericytosis (diffuse process in both cases) to myopericytosis to finally myopericytoma in case 1. Myopericytoma is a rare neoplasm which can arise from soft tissues, but also within organ systems $[10,11]$. A few case reports are available where the location was in the lung [6,21,30]. Myopericytoma is one of four entities listed within the group of pericytic tumors besides glomangiopericytoma, infantile myofibromatosis, and hemangiopericytoma $[11,13]$. Our first case morphologically fulfilled the classical pattern with primitive spindle cells and focal differentiation into smooth muscle as well as perivascular epithelioid cells (PEC) within the tumor. The second case presented with uniform epithelioid cells, without PEC, but focal myogenic differentiation. The immunohistochemical profile of both tumors was in line with what has been reported for myopericytomas, namely expression of smooth muscle actin and vimentin [7, 24]. Recently an activating mutation for PDGFRB was reported for myopericytoma [13]. A 
Table 2 Reaction of tumor cells from cases 1 and 2. Negativity for calretinin and podoplanin rules out mesothelioma, negativity for SMA and desmin rules out leiomyomatous tumors, and negativity for CD68, 45, and 35 rules out reticulum cell tumors. A negative reaction for $\mathrm{S} 100$ protein rules out nerve sheet tumors. nd not done, either because of limited tissue or because of negative staining in previous tissues; $f$ focal

\begin{tabular}{|c|c|c|c|c|}
\hline Antibody & Diffuse process OLB 2001 & Tumor cells OLB 2001 & Diffuse process biopsy 2006 & Tumor cells OLB 2006 \\
\hline \multicolumn{5}{|l|}{ Patient 1} \\
\hline Pancytokeratin & - & - & - & - \\
\hline CD 56 (NCAM) & nd & nd & - & - \\
\hline LCA CD45 & nd & - & nd & - \\
\hline S100 protein & nd & - & - & - \\
\hline Vimentin & + & + & + & + \\
\hline Desmin & - & - & nd & - \\
\hline Smooth muscle actin & - & $\mathrm{f}+$ & - & $\mathrm{f}+$ \\
\hline CD31 & - & - & - & - \\
\hline CD34 & - & $\mathrm{f}+$ & - & - \\
\hline CD68 & nd & - & nd & - \\
\hline Ki67 & $\geq 5 \%$ & $\geq 5 \%$ & $\geq 5 \%$ & $\geq 5 \%$ \\
\hline HMB45 & - & - & - & $\mathrm{f}++$ \\
\hline ER & nd & nd & nd & - \\
\hline PG & nd & nd & nd & + \\
\hline VEGF-A & ++ & ++ & + & + \\
\hline VEGFR-2 & - & - & nd & + \\
\hline VEGFR-3 & ++ & +++ & nd & ++ \\
\hline Endothel kinase Tie2 & ++ & ++ & nd & ++ \\
\hline cAMP kinase alpha & ++ & ++ & nd & nd \\
\hline Hamartin & - & - & nd & nd \\
\hline Tuberin & + & + & nd & nd \\
\hline Calretinin & - & - & - & - \\
\hline Podoplanin & - & - & - & - \\
\hline Factor VIIIAG & Tu-endothelia+ & & & \\
\hline HHV8 & - & - & - & - \\
\hline CD35 & - & - & - & - \\
\hline Patient 2 & Adenocarcinoma 2020 & Nodular and trabecular process 2020 & & \\
\hline Cytokeratin 7 & + & - & & \\
\hline CAM5.2 & + & - & & \\
\hline $\mathrm{AE} 1 / 3$ & + & - & & \\
\hline Chromogranin A & - & - & & \\
\hline Synaptophysin & - & - & & \\
\hline Estrogen receptor & - & - & & \\
\hline Progesterone receptor & - & + & & \\
\hline TTF1 & + & - & & \\
\hline P40 & - & - & & \\
\hline HMB45 & - & - & & \\
\hline MelanA & - & - & & \\
\hline MITF & - & - & & \\
\hline MIB1 & $12 \%$ & $<1 \%$ & & \\
\hline Vimentin & - & + & & \\
\hline Desmin & - & - & & \\
\hline Factor XIII & - & - & Vascular structures within nodules & \\
\hline ERG & - & - & & \\
\hline $\mathrm{S} 100$ protein & - & - & & \\
\hline SMA & - & + & & \\
\hline Caldesmon & - & Single cells+ & & \\
\hline MyoFD5 & - & Single cells+ & & \\
\hline VEGFR2 & - & + & & \\
\hline VEGFR3 & - & - & & \\
\hline Cathepsin K & - & - & & \\
\hline PDGFRB & - & + & & \\
\hline
\end{tabular}

low level of expression was reported. In our case 2, we found a moderate protein expression by immunohistochemistry.

Single case reports of myopericytomas have been reported in the lung. However, our cases are unique in the sense that they represent precursor lesions with a quite different morphological appearance, and in addition present with a tumor, arising out of this precursor lesion. In addition, we also present evidence for a more specific therapeutic intervention, using targeted therapy, which might inhibit angiogenesis. As both tumors are likely driven by VEGF 
Fig. 4 Immunohistochemistry for both cases: $\mathbf{a}$ and $\mathbf{b} \mathrm{CD} 31$ showing the vascular network in one nodule (a) and the diffuse infiltration (b) of case 1, bar 50 $\mu \mathrm{m}$; c CD31 expression in case 2, $\times 200$. d Expression of vimentin in one of the lesions of case $2, \times$ 200. Expression of VEGFR3 (e) in case 1 and VEGFR2 (f) in case 2. In VEGFR3, an antibody was used which detects the $\mathrm{C}$-terminal end of the receptor; the nuclear reaction might be interpreted that the kinase domain is translocated into the nucleus, whereas the expression of VEGFR2 is membranous. Bar $50 \mu \mathrm{m}$ and $\times$ 200. g Expression of SMA in the tumor of case 1 and in the proliferation of case 2 (h). Bar $20 \mu \mathrm{m}$ and $\times 200$. i Negative staining for cathepsin $\mathrm{K}$ and positive expression of PDGFRB (j), both in case 2. Bars $100 \mu \mathrm{m}$
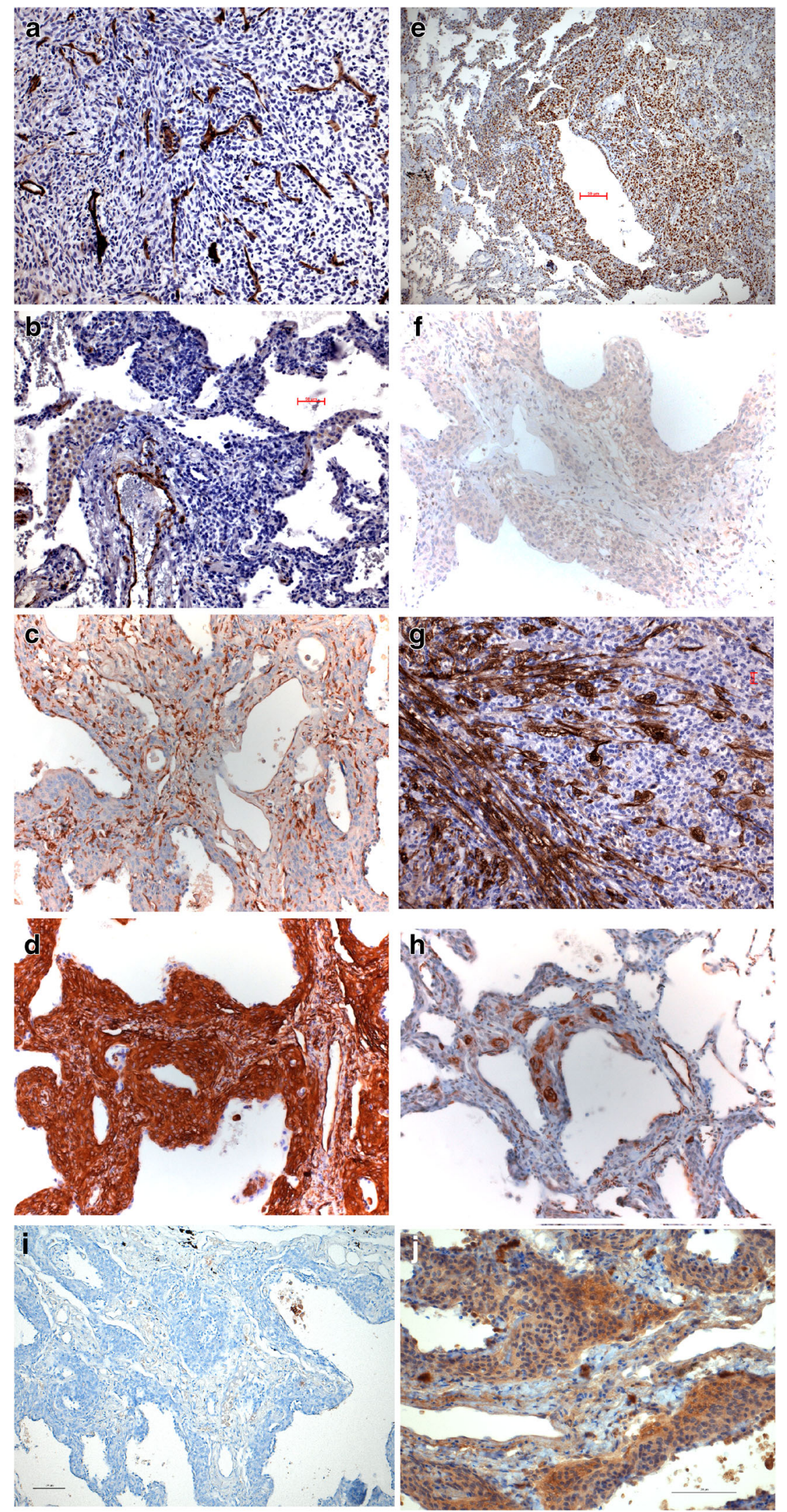

receptors, a more selective therapy available nowadays could inhibit these receptors and interfere not only with growth signaling in the large tumor but also in the diffuse proliferation, preceding the tumor. 
VEGF receptors play an important role in fetal organogenesis of the lung. VEGFR1 is predominantly driving angiogenesis in the central vascular system, whereas VEGFR2/3 plays a major role in directing the growth of the peripheral capillary and lymphatic net $[14,25]$. VEGFR2/3 also plays a role in low- and high-grade angiosarcomas $[19,31]$. Since pericytes and precursors in a fetal lung are also under the control of these growth factors, our findings suggest a possible way for treatment. Initially in case 1 , the antibody against VEGF, bevacizumab, approved 2005, was chosen. As inhibitors of angiogenesis carry a risk for bleeding, thrombosis, and hypertension [22], a drug targeting VEGFR 2 and 3 might selectively block the receptor. Pazopanib, a TKI inhibiting VEGFR, PDGFR, and c-KIT, approved for advanced renal cell carcinoma and advanced sarcoma of soft tissue, might be an option. Ramucirumab, a monoclonal antibody selective against VEGFR2 and approved for advanced gastric cancer, could be another option. A third option might be nintedanib, a TKI targeting PDGFR, FGFR, and VEGFR in this rare kind of tumors.

Additional tissues sections from case one could be relocated and stained for MITF, cathepsin K, and PDGFRB. MITF and cathepsin $\mathrm{K}$ were both negative in the myopericytoma and in myopericytosis. The reaction for PDGFRB was positive in the epitheloid cells of the myopericytoma, but negative in myopericytosis.

Authors' contribution UGM and HP have designed the study and wrote the draft; AMH and $\mathrm{KB}$ have contributed to the case analysis and worked together with UGM and HP on the final manuscript.

Funding Open access funding provided by Medical University of Graz.

\section{Compliance with ethical standards}

Conflict of interest The authors declare that they have no conflict of interest.

Open Access This article is licensed under a Creative Commons Attribution 4.0 International License, which permits use, sharing, adaptation, distribution and reproduction in any medium or format, as long as you give appropriate credit to the original author(s) and the source, provide a link to the Creative Commons licence, and indicate if changes were made. The images or other third party material in this article are included in the article's Creative Commons licence, unless indicated otherwise in a credit line to the material. If material is not included in the article's Creative Commons licence and your intended use is not permitted by statutory regulation or exceeds the permitted use, you will need to obtain permission directly from the copyright holder. To view a copy of this licence, visit http://creativecommons.org/licenses/by/4.0/.

\section{References}

1. Alt B, Huffer WE, Belchis DA (1983) A vascular lesion with smooth muscle differentiation presenting as a coin lesion in the lung: glomus tumor versus hemangiopericytoma. Am J Clin Pathol 80:765-771

2. Armulik A, Abramsson A, Betsholtz C (2005) Endothelial/pericyte interactions. Circ Res 97:512-523

3. Bonetti F, Pea M, Martignoni G, Doglioni C, Zamboni G, Capelli P, Rimondi P, Andrion A (1994) Clear cell ("sugar") tumor of the lung is a lesion strictly related to angiomyolipoma-the concept of a family of lesions characterized by the presence of the perivascular epithelioid cells (PEC). Pathology 26:230-236

4. Brega Massone PP, Lequaglie C, Conti B, Ferro F, Magnani B, Cataldo I (2002) A particular case with long-term follow-up of rare malignant hemangiopericytoma of the lung with metachronous diaphragmatic metastasis. Thorac Cardiovasc Surg 50:178-180

5. Caliò A, Mengoli MC, Cavazza A, Rossi G, Ghimenton C, Brunelli M, Pea M, Chilosi M, Marcolini L, Martignoni G (2018) Cathepsin $\mathrm{K}$ expression in clear cell "sugar" tumor (PEComa) of the lung. Virchows Arch 473:55-59. https://doi.org/10.1007/s00428-0182325-1

6. Cao JH, Xu JP, Li YC, Lai J, Li Q (2009) Pulmonary myopericytoma: a case report and review of the literatures. Chin Med J 122:755-757

7. Coffin CM, Neilson KA, Ingels S, Frank-Gerszberg R, Dehner LP (1995) Congenital generalized myofibromatosis: a disseminated angiocentric myofibromatosis. Pediatr Pathol Lab Med 15:571-587

8. Dray MS, McCarthy SW, Palmer AA, Bonar SF, Stalley PD, Marjoniemi V, Millar E, Scolyer RA (2006) Myopericytoma: a unifying term for a spectrum of tumours that show overlapping features with myofibroma. A review of 14 cases. J Clin Pathol 59:67-73. https://doi.org/10.1136/jcp.2005.028704

9. Gaertner EM, Steinberg DM, Huber M, Hayashi T, Tsuda N, Askin FB, Bell SW, Nguyen B, Colby TV, Nishimura SL, Miettinen M, Travis WD (2000) Pulmonary and mediastinal glomus tumorsreport of five cases including a pulmonary glomangiosarcoma: a clinicopathologic study with literature review. Am J Surg Pathol 24:1105-1114

10. Gengler C, Guillou L (2006) Solitary fibrous tumour and haemangiopericytoma: evolution of a concept. Histopathology 48:63-74

11. Granter SR, Badizadegan K, Fletcher CD (1998) Myofibromatosis in adults, glomangiopericytoma, and myopericytoma: a spectrum of tumors showing perivascular myoid differentiation. Am J Surg Pathol 22:513-525

12. Hansen CP, Francis D, Bertelsen S (1990) Primary hemangiopericytoma of the lung. Case report. Scand J Thorac Cardiovasc Surg 24:89-92

13. Hung YP, Fletcher CDM (2017) Myopericytomatosis: clinicopathologic analysis of 11 cases with molecular identification of recurrent PDGFRB alterations in myopericytomatosis and myopericytoma. Am J Surg Pathol 41:1034-1044. https://doi.org/ 10.1097/pas.0000000000000862

14. Janer J, Lassus P, Haglund C, Paavonen K, Alitalo K, Andersson S (2006) Pulmonary vascular endothelial growth factor-C in development and lung injury in preterm infants. Am J Respir Crit Care Med 174:326-330. https://doi.org/10.1164/rccm.200508-1291OC

15. Johnson JA 3rd, Warren ET, Heath BJ (1992) Primary pulmonary hemangiopericytoma in a 3-year-old child. Tex Heart Inst J 19:146147

16. Katabami M, Okamoto K, Ito K, Kimura K, Kaji H (2006) Bronchogenic glomangiomyoma with local intravenous infiltration. Eur Respir J 28:1060-1064

17. Kuroya M, Yokomise H, Inui K, Ike O, Mizuno H, Wada H, Hitomi S (1996) Resection of primary pulmonary hemangiopericytoma: a report of two cases. Surg Today 26:208-212

18. Martignoni G, Bonetti F, Chilosi M, Brunelli M, Segala D, Amin MB, Argani P, Eble JN, Gobbo S, Pea M (2012) Cathepsin K expression in the spectrum of perivascular epithelioid cell (PEC) 
lesions of the kidney. Mod Pathol 25:100-111. https://doi.org/10. 1038/modpathol.2011.136

19. Miettinen M, Rikala MS, Rys J, Lasota J, Wang ZF (2012) Vascular endothelial growth factor receptor 2 as a marker for malignant vascular tumors and mesothelioma: an immunohistochemical study of 262 vascular endothelial and 1640 nonvascular tumors. Am J Surg Pathol 36:629-639. https://doi.org/10.1097/ PAS.0b013e318243555b

20. Miller DL, Allen MS (1993) Rare pulmonary neoplasms. Mayo Clin Proc 68:492-498

21. Mun JM, Kim JI, Ko TY, Park SD (2018) Surgical treatment of primary pulmonary myopericytoma. Korean J Thorac Cardiovasc Surg 51:220-222. https://doi.org/10.5090/kjtcs.2018.51.3.220

22. Pandey AK, Singhi EK, Arroyo JP, Ikizler TA, Gould ER, Brown J, Beckman JA, Harrison DG, Moslehi J (2018) Mechanisms of VEGF (vascular endothelial growth factor) inhibitor-associated hypertension and vascular disease. Hypertension 71:e1-e8. https:// doi.org/10.1161/HYPERTENSIONAHA.117.10271

23. Popper HH, Juettner-Smolle FM, Pongratz MG (1991) Micronodular hyperplasia of type II pneumocytes-a new lung lesion associated with tuberous sclerosis. Histopathology 18:347354

24. Porter PL, Bigler SA, McNutt M, Gown AM (1991) The immunophenotype of hemangiopericytomas and glomus tumors, with special reference to muscle protein expression: an immunohistochemical study and review of the literature. Mod Pathol 4: $46-52$

25. Rajatapiti P, van der Horst IW, de Rooij JD, Tran MG, Maxwell $\mathrm{PH}$, Tibboel D, Rottier R, de Krijger RR (2008) Expression of hypoxia-inducible factors in normal human lung development. Pediatr Dev Pathol 11:193-199. https://doi.org/10.2350/07-040257.1

26. Robinson DR, Wu YM, Kalyana-Sundaram S, Cao X, Lonigro RJ, Sung YS, Chen CL, Zhang L, Wang R, Su F, Iyer MK, Roychowdhury S, Siddiqui J, Pienta KJ, Kunju LP, Talpaz M,
Mosquera JM, Singer S, Schuetze SM, Antonescu CR, Chinnaiyan AM (2013) Identification of recurrent NAB2-STAT6 gene fusions in solitary fibrous tumor by integrative sequencing. Nat Genet 45:180-185. https://doi.org/10.1038/ng.2509

27. Rossle M, Bayerle W, Lohrs U (2006) Glomangioma of the lungs: a rare differential diagnosis of a pulmonary tumour. J Clin Pathol 59: 1000

28. Santambrogio L, Nosotti M, Palleschi A, Gazzano G, De Simone M, Cioffi U (2011) Primary pulmonary glomangioma: a coin lesion negative on PET study. Case report and literature review. Thorac Cardiovasc Surg 59:380-382. https://doi.org/10.1055/s-00301250577

29. Sekine I, Kodama T, Yokose T, Nishiwaki Y, Suzuki K, Goto K, Nagai K, Kuriyama T (1998) Rare pulmonary tumors - a review of 32 cases. Oncology 55:431-434

30. Song XL, Sun XY, Zhang GL, Yu YW, Wang CH (2012) Myopericytoma presenting as multiple pulmonary nodules. Intern Med 51:639-642. https://doi.org/10.2169/internalmedicine.51. 6531

31. Stacher E, Gruber-Mosenbacher U, Halbwedl I, Dei Tos AP, Cavazza A, Papotti M, Carvalho L, Huber M, Ermert L, Popper HH (2009) The VEGF-system in primary pulmonary angiosarcomas and haemangioendotheliomas: new potential therapeutic targets? Lung Cancer 65:49-55. https://doi.org/10.1016/j. lungcan.2008.10.031

32. Van Damme H, Dekoster G, Creemers E, Hermans G, Limet R (1990) Primary pulmonary hemangiopericytoma: early local recurrence after perioperative rupture of the giant tumor mass (two cases). Surgery 108:105-109

33. Yousem SA, Hochholzer L (1987) Primary pulmonary hemangiopericytoma. Cancer 59:549-555

Publisher's note Springer Nature remains neutral with regard to jurisdictional claims in published maps and institutional affiliations. 